\title{
サトウキビ畑における土壤物理性および地下浸透量の推定に土壌サンプリン グ時期の違いが及ぼす影響
}

\author{
岡本健 ${ }^{1} \cdot$ 酒井一人 $^{2} \cdot$ 仲村渠将 $^{3} \cdot$ 後藤慎吉 $^{4}$
}

\section{Effects of Soil Sampling Time on Soil Physical Parameters and Infiltration in Sugarcane Fields}

\author{
Ken Okamoto ${ }^{1}$, Kazuhito Sakai ${ }^{2}$, Tamotsu Nakandakari ${ }^{3}$ and Shinkichi Goto ${ }^{4}$
}

\begin{abstract}
On the small islands of Okinawa, reliance on groundwater is high. The main land use in areas of groundwater recharge is sugarcane fields. To model groundwater recharge in these fields, it is important to analyze infiltration, so the appropriate choice of soil hydraulic parameters is important. Sugarcane crops can take up to 2 years to mature, so the effects of time on soil physical parameters and groundwater recharge need to be considered. To model groundwater recharge, we collected 49 soil core samples 4 times in $2 \frac{1}{2}$ years in 7 fields and measured soil physical parameters. Using cluster analysis, we classified the data and groundwater recharge, which was simulated in Hydrus-1D software. Values of bulk density, saturated hydraulic conductivity, and soil hydraulic parameter $n$ were related to time after planting. Cluster analysis identified 4 clusters according to groundwater recharge rate and soil physical condition, and the results were affected by the time of sampling. These results indicate that it is necessary to take sampling date into account while simulating groundwater recharge in sugarcane fields.
\end{abstract}

Keywords: Time variation; Bulk density; Mualem-van Genuchten parameters; Infiltration; Cluster analysis

\section{1 はじめに}

沖縄県の小離島においては, 地下水への依存度が高く, サトウキビ畑は土地利用の多くの割合を占める重要な地 下水涵養源である.地下水の水循環においては，表層は 大気との境界領域にあたる.気候変動下においては, 温 暖化による蒸散量の増加・降雨特性の変動による地下浸 透量の変化が予測され, 表層の水循環の変化による地下 水資源量の減少が懸念されている. そのため, 宮古島で は, 気候変動下における将来予測可能な, 飽和一不飽和 の浸透解析モデルの構築が期待されている.

不飽和浸透解析においては, 適切な土壤水分特性の パラメータの推定が求められる. 流域規模の解析において は，土畩物理性の空間分布を把握することが重要であり， 土壤物理性および土壌構造の空間分布についての研究 が進められてきた(例えば, 坂本ら，2003)。一方，土壤物 理性, 特に土壤構造は時間変動を持つことでも知られて いる. 長谷川・前田(1977)によると, 土壌構造は, 耕転とい った営農の履歴, 乾湿の繰り返しと気象要因によって, 時 間変動を持つと報告されている. また, 㴊上ら(1993)の報

\footnotetext{
1 琉球大学農学部協力研究員, Cooperative Researcher, Faculty of Agriculture, University of the Ryukyus, 1 Senbaru, Nishihara-cho, Okinawa, 903-0213 Japan (Corresponding Author) E-mail:kenokamoto@ affrc.go.jp

2 琉球大学農学部教授, Professor, Faculty of Agriculture, University of the Ryukyus, 1 Senbaru, Nishihara-cho, Okinawa, 903-0213, Japan

3 琉球大学農学部准教授, Associate Professor, Faculty of Agriculture, University of the Ryukyus, 1 Senbaru, Nishihara-cho, Okinawa 903-0213, Japan

4 国際農林水産業研究センター熱帯 ・島嶼研究拠点主任研究員, Senior Researcher, Tropical Agriculture Research Front, Japan International Research Center for Agriculture Sciences, 1091-1 Kawarabaru, Maezato, Ishigaki-city, Okinawa 907-0002, Japan
}

告によると, 締め固まった土壌の乾燥密度に比べて, 耕地 土壤の乾燥密度は耕転の影響により時間変動が大きいこ とが指摘されている. サトウキビ栽培では, 長い植付け期 間 (1〜2年半)を要する.このような戋場においては, 土壤 サンプリングの時期により土壌構造が変化することが予測 され, 不飽和浸透解析に用いる土壌のサンプリング時期 の違いにより, 浸透量の算定に影響を及ぼすことが推定さ れる.

以上のような背景より, サ卜ウキビ畑における不飽和浸透 解析に用いる土壌パラメータのサンプリング時期の違いの 影響把握といら観点から, 本研究ではまず, 宮古島の白川 田地下水流域のサトウキビ栽培を行っていた7固場より, 2011年から2013年の間に49試料の土壌サンプリングを行 い, 土壊物理試験により求めた水分移動特性関数のパラ メータを用いて, 不飽和浸透解析を行い, 浸透量を推定し た. 不飽和浸透解析には, Okamoto et al. (2015)により, 同 流域のサトウキビ栽培圃場の土壌水分動態への適用性が 検証されているHYDRUS-1Dを用いた. 土壌物理性, 水 分移動特性関数パラメータ, 植付け後からの経過時間お よび浸透量の推定值を変数として, 変数間の相関関係の 把握を行った.さらに, クラスター分析を行い土䁃サンプル の類型化を行い, 浸透量の確率水文量を推定し, 類型化 されたクラスターの違いが確率水文量の推定に及ぼす影 響を検討した。

\section{2 素材および方法}

\section{1 対象流域および土壤サンプリング}

本研究の対象は, 宮古島の水道水源流域として指定され ている白川田地下水流域とした. 既往の白川田地下水流 
域の調査報告 (宮古島上下水道企業団, 1999)によると, 流域面積は $10.3 \mathrm{~km}^{2}$ であり, 主な土地利用は, 耕地: $68.7 \%$, 森林: $22.7 \%$, その他 $8.6 \%$ (道路, ビニールハウス, 浸透池 等)の順で利用されている. また, 耕地の主な植付け作物 はサ卜ウキビである. 流域の地質構造は, 多孔質で透水性 の高い琉球石灰岩の上に, 透水性の高い土壌層が覆う. 島尻マージ (暗赤色土壌) に分類される土壤が流域に 主に分布する. 宮古島における水収支の推定は，地下 ダム建設時に数多く報告されており（例えば，田中・ 四厅所, 1981：相場ら，1988：今泉ら，1988），それ らの調査をまとめた黒田・古川(2002)によると，宮古 島の水収支は蒸発散 : 地下浸透 : 表面流出 $=0.5: 0.4$ : 0.1である. 図 1に, サンプリングを行ったサトウキビ 栽培7固場と宮古島の地下水流域図（宮古島市，2011） を示す.

土壌サンプリングは2011年から2013年の間に複数回行 った. 調查圃場でのサンプリングでは, 表層土 $(0-10 \mathrm{~cm})$ の 擋乱土および不擋乱土 $\left(100 \mathrm{~cm}^{3}\right.$ コアサンプラー) 畧間よ り49試料採取した. 採取した土壤サンプルは, 琉球大学の 実験室に持ち帰り, 土壤物理試験に供した. 土壌物理試 験では, 粒度分布, 乾燥密度, 飽和透水係数および水分 特性曲線の測定を行った. 粒度分布は, 擋乱試料を用い て, JIS法に準拠して測定を行った. また, 不擋乱試料を用 いて, 飽和透水係数 (定水位法), 水分特性曲線 (吸引法, 加圧板法), 乾燥密度 (24時間 110 度炉乾燥) の順で測定 を行った. 飽和透水係数および水分特性曲線の測定にお けるサンプルの飽和では, 土壤サンプルの崩壊を避ける ために24時間毛管飽和を行い, 水分特性曲線は毛管飽

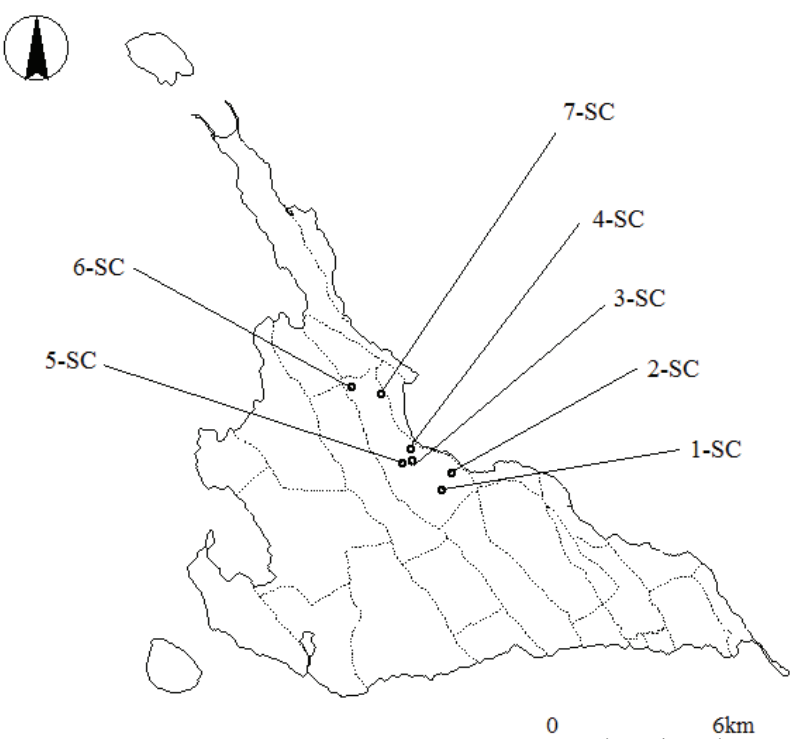

図 1: 宮古島における地下水流域界と土壌サンプリング地 点(破線は地下水流域境界)

表 1: 49土䁃サンプルの粒度分布, 乾燥密度および飽和 透水係数の統計值

\begin{tabular}{lccccc}
\hline & & 平均 & 標準 & 最大 & 最小 \\
& & 值 & 偏差 & 值 & 值 \\
\hline 砂 & $(\%)$ & 11.3 & 5.2 & 22.0 & 2.4 \\
シルト & $(\%)$ & 41.0 & 8.6 & 54.3 & 10.1 \\
粘土 & $(\%)$ & 47.7 & 12.3 & 87.5 & 23.7 \\
乾燥密度 & $\left(\mathrm{g} \mathrm{cm}^{-3}\right)$ & 1.13 & 0.13 & 1.45 & 0.86 \\
飽和透水係数 & $\left(\mathrm{cm} \mathrm{d}^{-1}\right)$ & 1772 & 2148 & 9363 & 11 \\
\hline
\end{tabular}

和から土㙋吸引圧 $-10000 \mathrm{~cm}$ の範囲で測定を行った. 表 1 に粒度分布, 乾燥密度および飽和透水係数の統計值, 困 2 に水分特性曲線のそれぞれの土壤吸引圧の体積含水 率の平均值および標準偏差を示す。

\section{2 土壤サンプリング時における対象圃場のサトウキ ビ植付け後経過期間}

土壤サンプリング時のサトウキビの生育状況の確認お よび農家への聞き取りより，それぞれの圃場のサトウ キビの栽培型の把握を行い, 耕起後からの経過時間の 推定を行った。栽培型による栽培管理は, 沖縄県のサ トウキビ栽培指針（沖縄県農林水産部, 2014）に従い, 夏植え栽培; 8 月植付け翌々年1月収穫, 春植え栽培; 2 月植付けの翌年1月収穫, 株出し栽培; 前作収穫の翌年 1月収穫とした。なお，株出し栽培とは，収穫後，地下 株から萌芽する芽を肥培管理し，再度収穫する作型で ある. 本調査を行ったサンプリング時期の6, 12 月では, 夏植え栽培と他の栽培型は, 植付け時期および植付け 期間の違いのため, 茥長の生育状況を目視することに より容易に判別できるが, 春植え栽培および株出し栽 培の栽培型の判別は困難である。それぞれの栽培型に おける耕起は, 春植えおよび夏植え栽培では植付けの1 か月前（夏植え栽培 $=7$ 月，春植え栽培 $=1$ 月），株出 し栽培では収穫後1週間以内に行われる.株出し栽培と 春植え栽培では，同じ時期における苗の植付け後から の間隔は大きく変わるが，耕起後からの間隔は概ね同 じであると言える。したがって，夏植え栽培とその他 の栽培型に分類し，土壌サンプリング時の植付け後か らの経過期間を決定した（表 2）。なお，農家への聞 き取りより，2011年1月のサンプリング時の圃場は，全 て夏植え栽培の収穫後の圃場であった。

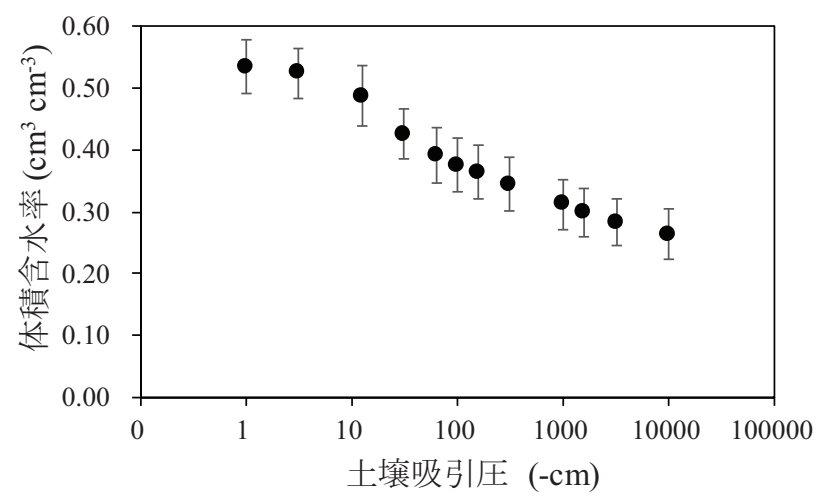

図 2: 49 土㙋サンプルの水分特性曲線(黒丸マーカ 一;平均值, エラーバー;標準偏差)

表 2: 土壌サンプリング時における植付け後経過期 間 $(*=$ 夏植え栽培, 0 力月=耕起後かつ植付け前 $)$

\begin{tabular}{|c|c|c|c|c|}
\hline サンプリ & \multicolumn{4}{|c|}{ サンプリング時期（年/月） } \\
\hline ング地点 & $2011 / 1$ & $2011 / 12$ & $2012 / 12$ & 2013/06 \\
\hline $1-\mathrm{SC}$ & 18か月* & 11か月 & 11か月 & 5か月 \\
\hline 2-SC & 18か月* & - & 17か月* & - \\
\hline $3-\mathrm{SC}$ & 18か月* & 4か月* & 17か月* & 5か月 \\
\hline 4-SC & 18か月* & 4か月* & 17か月* & 5か月 \\
\hline $5-\mathrm{SC}$ & 18か月* & 0か月 & 11か月 & 5か月 \\
\hline 6-SC & 18か月* & 4か月* & 17か月* & 0か月* \\
\hline 7-SC & 18か月* & 11か月 & 11か月 & 5か月 \\
\hline
\end{tabular}




\section{3 長期不飽和浸透解析}

長期不飽和浸透解析では, 1980年から2009年の30年間 を対象として, 気象データは宮古島気象台のデータを利 用し, HYDRUS-1Dを用いた。

\subsubsection{HYDRUS-1Dの概要}

HYDRUS-1Dは土壌内の水分, 熱および溶質輸送の予測 シミュレーションモデルである. 土壤内の水分移動の基礎 方程式は, 式(1)のリチャーズ式で表されられる.

$$
\frac{\partial \theta}{\partial t}=\frac{\partial}{\partial z}\left[K(h)\left(\frac{\partial h}{\partial z}+1\right)\right]-S
$$

ここで, $\theta$ は体積含水率 $\left(\mathrm{cm}^{3} \mathrm{~cm}^{-3}\right), t$ は時間(d), $z$ は地 表面からの鉛直距離 $(\mathrm{cm}), h$ は土袞吸引圧 $(\mathrm{cm}), \quad K(h)$ は不飽和透水係数 $\left(\mathrm{cm} \mathrm{d}^{-1}\right), S$ は吸水項 $\left(\mathrm{cm}^{3} \mathrm{~cm}^{-3} \mathrm{~d}^{-1}\right)$ であ る.

水分移動特性関数は, mualem-van Genuchten(Mualem, 1976: van Genuchten, 1980，以降MVG)モデルを採用し た.

$$
\begin{gathered}
S_{e}=\frac{\theta-\theta_{r}}{\theta_{s}-\theta_{r}}=\left(1+|\alpha h|^{n}\right)^{-m} \\
K(h)=K_{s} S_{e}{ }^{l}\left[1-S_{e}\left(1-S_{e} e^{1 / m}\right)^{m}\right]^{2}
\end{gathered}
$$

ここで, $S_{e}$ は有効飽和度 $(-), \theta_{r}$ は残留体積含水率 $\left(\mathrm{cm}^{3}\right.$ $\left.\mathrm{cm}^{-3}\right), \theta_{s}$ は飽和体積含水率 $\left(\mathrm{cm}^{3} \mathrm{~cm}^{-3}\right), \alpha$ はフィッテイング パラメータ $\left(\mathrm{cm}^{-1}\right), n, m(=1-1 / n), l(=0.5)$ はフィッティングパ ラメータ $(-), K_{s}$ は飽和透水係数 $\left(\mathrm{cm} \mathrm{d}^{-1}\right)$ である. 式(2)の $\theta_{r}$, $\theta_{s}, \alpha, n$ は, 水分特性曲線の試験結果をRETCプログラム (USDA Agriculture research service)に適用して求め, $K_{s}$ は 飽和透水係数の測定值を用いた. 表 3 にRETCに適用し て求めた 49 の土壌サンプルの $\theta_{r}, \theta_{s}, \alpha$ およびnの統計值を 示す.

\subsection{2 残留体積含水率 $\theta_{\text {，の設定 }}$}

残留体積含水率 $\theta_{r}$ は, 水分特性曲線の関数の適合性を 向上させるのに不可欠なパラメータであるが, その定義や 取り扱いについては議論が絶えない(小杉, 2007). Luckner et al. (1989)によると, $\theta_{r}$ は物理的意味合いをもつ パラメータであると定義されているが, Nimmo(1991)による と, $\theta_{r}$ はフィッティングパラメータの要素が強いと報告されて いる. 本研究の土袞サンプルでは, RETCの適用により8サ ンプルの $\theta_{r}$ が $0 \mathrm{~cm}^{3} \mathrm{~cm}^{-3}$ であった. $\theta_{r}$ の測定はルール化さ れてはおらず, 実用上の観点から永久しおれ点 $(-h=15000 \mathrm{~cm})$ の体積含水率が用いられることがある(van Genuchten, 1980). 図 3 に $\theta_{r}=0$ およよ゙ $\theta_{r}>0$ 以上にグループ 分けを行い, その平均值 $(\mathrm{a}, \mathrm{b})$ とa, bのフィッティング線 (c, d) および a , b の $\theta_{r}$ に $-h=10000 \mathrm{~cm} の$ 体積含水率

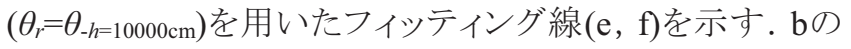

表 3: 49土壌サンプルの $\theta_{r}, \theta_{s}, \alpha, n$ のフィッティング值の 統計值

\begin{tabular}{cccccc}
\hline & & 平均值 & $\begin{array}{c}\text { 標隻 } \\
\text { 偏差 }\end{array}$ & 最大值 & 最小值 \\
\hline$\theta_{r}$ & $\left(\mathrm{~cm}^{3} \mathrm{~cm}^{-3}\right)$ & 0.184 & 0.104 & 0.314 & 0 \\
$\theta_{s}$ & $\left(\mathrm{~cm}^{3} \mathrm{~cm}^{-3}\right)$ & 0.542 & 0.045 & 0.626 & 0.445 \\
$\alpha$ & $\left(\mathrm{cm}^{-1}\right)$ & 0.168 & 0.174 & 0.700 & 0.009 \\
$n$ & $(-)$ & 1.364 & 0.276 & 2.226 & 1.074 \\
\hline
\end{tabular}

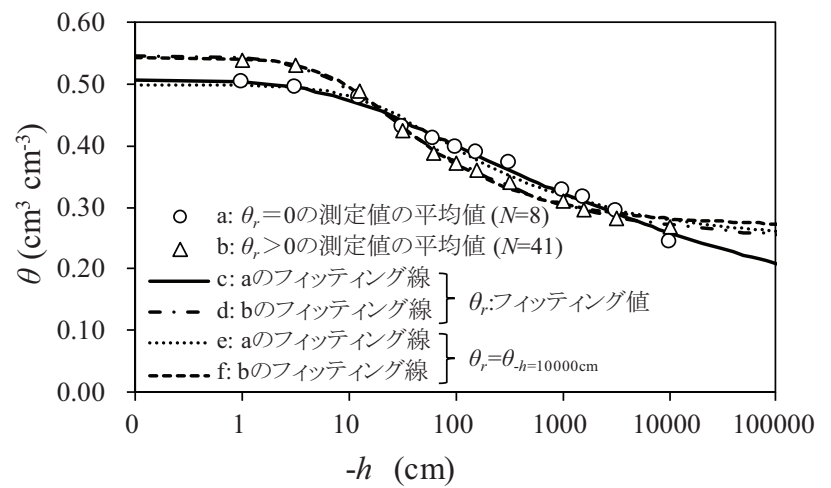

図 3: $\theta_{r}$ のフイッテイング值および $\theta_{r}=\theta_{-h=10000 \mathrm{~cm}}$ の違いに よる水分特性曲線の推定の影響 $(N$; サンプル数 $)$

水分特性曲線ではS字型の形状を確認することができるが, $\mathrm{a}$ の水分特性曲線では土壤吸引圧の低下による急激な体 積含水率の低下は起こらず, 緩やかに低下し続けた。乾

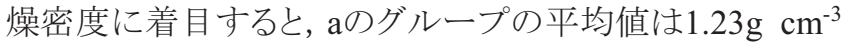

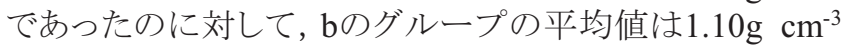
であり, aの土壌はよく締め固まっていた.したがって, $\mathrm{a} の$ グループの土壤では, 微細な間隙が多く, 低い土壤吸引 圧においても土㙵水分の変化量が、に比べて多くなったと 考えられた. c f 引圧の範囲で測定值を良好に再現した. $\theta_{r}=\theta_{-h=10000 \mathrm{~cm}}$ とし た e のフィッティング線は, $-h=10000 \mathrm{~cm}$ 近傍から $\theta_{r}\left(=0.244 \mathrm{~cm}^{3} \mathrm{~cm}^{-3}\right)$ の漸近線となっているため, 緩やかに 水分量が減っていくaの水分特性曲線を再現していないと 考えられた. 本試験では, $-h=10000 \mathrm{~cm}$ より低い土畩吸引 圧の水分特性曲線の測定は行っていないが, Okamoto et al. (2015) による同一流域内の水分特性曲線の van

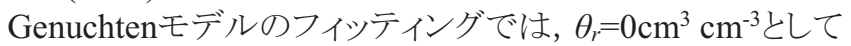
も- $10000 \mathrm{~cm}$ より低い土㙵吸引圧の水分特性曲線を良く再 現した. また, $\theta_{r}$ の定義からすると, 絶乾状態まで液状水の 移動が起こっていることを意味するが, 宮古島の年降雨は $2000 \mathrm{~mm}$ 以上であり, 実围場では, 極端な乾燥状態が起こ らないと考えられる. 不飽和浸透解析では, 実測に即した パラメータを用いることが重要であり, より実測の水分特性 曲線を再現することができる $\theta_{r}$ のフィッティング值を, HYDRUS-1Dの計算に用いた.

\subsection{3 計算条件}

本研究では, 7 圑場の表層土 $(0-10 \mathrm{~cm})$ の土壌サンプリング を行ったが, 営農の関係上, 深度別のサンプリングを行え なかった. そのため, 各戋場の土層厚 (計算領域) および 深さ方向の水分移動特性関数のパラメータは次のように 設定した. 翁長・宜保(1984)によると, 島尻マージは石灰 岩基盤であるため土層が薄い. 対象流域内においても, 地表面に石灰岩が露出している地点を確認できた. 沖縄 県の圃場整備事業においては, サトウキビ畑の有効土層 は40-60 cm確保されているが, 流域内の土壌層の厚さは, 面的なばらつきがあり, $100 \mathrm{~cm}$ 以上の土層厚のある圑場の 調査例も報告されている(Okamoto et al., 2015). また, サ卜 ウキビは深根性であり根は下方に伸びるが, 土壌水分消 費型としては, 表層で高く, 深さの増加に伴って減少して い表層消費型である(吉永・酒井, 2004). 土壌水分消費 型と根群域分布は密接な関係があり, 石灰岩土壌地帯で は 40〜 50cmの深さまでに根群域の $95 \%$ が分布している 
（山城, 1983）。そこで, 計算領域を $100 \mathrm{~cm}$ として, 根の最 大深さ (有効根群域の下端)を $60 \mathrm{~cm}$ とすることにより, 根の 最大深さより深い層の上向きの水分移動には十分な層が 確保できると判断した. 深さ方向の土壌水分特性は表層

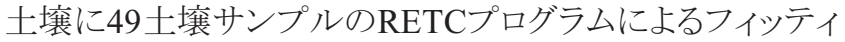
ング值および $K_{s}$ の測定值を用い, 表層より深い層では既 往の調査結果(Okamoto et al., 2015)による $\theta_{r}, \theta_{s}, \alpha, n$ のフ イッティング值および $K_{s}$ の測定值を採用した. 計算土層は6 層の土層を設定し, 地表面から0-10cm，10-20cm， 20-40cm, 40-60cm, 60-80cm, 80-100cmとした(表 4). な お, 表 $400-10 \mathrm{~cm}$ 水分移動特性関数パラメータは, そ れぞれ49土畩サンプルの平均值を示す.このように, 計算 領域および表層より深い層の土壤水分特性を同じ条件に することにより, 表層土壌のサンプリング時期の違いが計 算に及ぼす影響を検討する。

上端境界条件には, 可能蒸発量および降雨を与えた。 可能蒸発散量の推定には, 畑地灌溉計画の可能蒸発散 量の算定において推奨されている, Penman法を用いた (農林水産省, 1997). 式(4)および式(5)によってサトウキビ の葉面積指数を用いて, 可能蒸発量および可能蒸散量に 分離した(Campbell, 1988).

$$
\begin{gathered}
T_{p}=E T_{p}[1-\exp (-8.2 L A I)] \\
E_{p}=E T_{p}-T_{p}
\end{gathered}
$$

ここで， $T_{p}$ は日可能蒸散量 $\left(\mathrm{cm} \mathrm{d}^{-1}\right), E T_{p}$ は日可能蒸発 散量 $\left(\mathrm{cm} \mathrm{d}^{-1}\right), E_{p}$ は日可能蒸発量 $\left(\mathrm{cm} \mathrm{d}^{-1}\right), L A I$ は葉面積 指数(-)である。下端の境界条件は圧力勾配ゼロの自由 排水とした。

宮古島では，冬場の降雨量が少なく，土壌水分の年 変動は小さいと考えられることから，1979年12月31日 の土壤水分状態を土壤水分の初期条件とした。計算期 間の前年1979年の一年分の気象データを用いて，1979 年12月31日の体積含水率を, 裸地条件でHYDRUS-1D で計算した結果を上記の初期条件の初期值として設定 した. なお，この初期值を計算する際の初期条件 (1979 年1月1日の土壤水分状態) は一様な土壤吸引圧であり, 具体的には土壤吸引圧 $-100 \mathrm{~cm}$ をとの初期值とした。

\subsection{4 吸水項のモデル化}

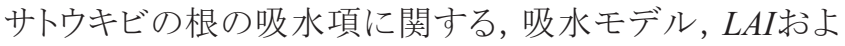
び根の生長関数を表 5に示す. それぞれのパラメータは, 宮古島で最も多い栽培型である, 夏植え栽培 (宮古農林 水産振興センター, 2011)の調査データを用いて決定した. 吸水量減少モデルは $\mathrm{S}$ 型関数モデル(van Genuchten, 1987)を適用し, パラメータはOkamoto et al. (2015)で用い た值を採用した。LAIは, 宮里(1986)の調査結果を, Larsbo and Jarvis (2003)のLAI生長関数に適用した. 根の

表 4: 深さ方向の水分移動特性関数パラメータ

\begin{tabular}{cccccc}
\hline $\begin{array}{c}\mathrm{Z} \\
(\mathrm{cm})\end{array}$ & $\begin{array}{c}\theta_{r} \\
\left(\mathrm{~cm}^{3}\right. \\
\left.\mathrm{cm}^{-3}\right)\end{array}$ & $\begin{array}{c}\theta_{s} \\
\left(\mathrm{~cm}^{3}\right. \\
\left.\mathrm{cm}^{-3}\right)\end{array}$ & $\begin{array}{c}\alpha \\
\left(\mathrm{cm}^{-1}\right)\end{array}$ & $\begin{array}{c}n \\
(-)\end{array}$ & $\begin{array}{c}K_{s} \\
\left(\mathrm{~cm} \mathrm{~d}^{-1}\right)\end{array}$ \\
\hline $0-10$ & 0.184 & 0.542 & 0.1675 & 1.364 & 1771.9 \\
$10-20$ & 0 & 0.493 & 0.0037 & 1.193 & 24.7 \\
$20-40$ & 0 & 0.493 & 0.0148 & 1.140 & 24.3 \\
$40-60$ & 0 & 0.449 & 0.0117 & 1.125 & 21.8 \\
$60-80$ & 0 & 0.462 & 0.0107 & 1.147 & 116.3 \\
$80-100$ & 0 & 0.556 & 0.0082 & 1.166 & 21.9 \\
\hline
\end{tabular}

表 5: 根による吸水モデルおよびサトウキビ生長モデル

\begin{tabular}{ll}
\hline モデル & 出典 \\
\hline 吸水量減少モデル & van Genuchten (1987) \\
$L A I$ & Larsbo and Jarvis (2003) \\
最大根の深さ & Šimůnek and Suarez (1993) \\
根群域分布 & Hoffman and van Genuchten (1983) \\
\hline
\end{tabular}

最大深さは, LAIが最大となる日（植付け後経過日数: 372 日）に，60 cmと設定した。また，植付け日を $1 \mathrm{cm，}$ 植付け日と根の深さが最大となる日の中間の日 (植付け後

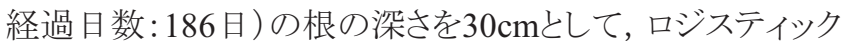
生長関数(Šimůnek and Suarez, 1993)に適用した.

\section{4 クラスター分析による類型化および確率水文量の 推定}

土壤サンプルの植付け後経過期間, 土壤物理試験結果 および計算期間の年浸透量の平均值をクラスター分析に 用いる変数とし, まず変数間の相関関係を検討した. 次に, それぞれの変数はスケールが異なるため, 変数の標準化 (平均0, 分散1)を行い, x-means法によるクラスター分析を 行い類型化した. x-means法は, k-means法と同様に非階 層的方法の分類方法であるが, k-means法と違い, 最適な クラスター数を決定するアルゴリズムを持つ. クラスター分 析には統計解析ソフト R version3.3.2を使用し, x-means 法のプログロムのソースコードは, 石岡(2000)によって公開 されているウェブ上のコードを使用した。

確率水文量として, 用水計画の計画基準年として用いら れる10年確率の年雨量および年浸透量を推定した. 非超 過確率の計算には次式のワイブルプロット(Weibull plot)を 用いた。

$$
P\left(x_{i}\right)=\frac{i}{N+1}
$$

ここで, $N$ はサンプル数, $x_{i}$ は小さいほうから数えて $i$ 番目に 位置する $i$ 番目順序統計量, $P\left(x_{i}\right)$ は $x_{i}$ が非超過確率に換 算された值である. 非超過確率, 年地下浸透量は対数正 規確率紙にプロットし, 最小二乗法を用いて直線回帰を行 った.

\section{3 結果と考察}

\section{1 変数の相関関係}

表 6に土壌物理試験結果, $\mathrm{MVG}$ パラメータ, 植付け後経 過時間および計算期間の年浸透量の平均值の相関関係 を示す.

粒度分布では, シルトおよび粘土は $\theta_{s}$ と高い相関関係 (シルト: $r=-0.68$, 粘土: $r=0.68$ )を示し, 乾燥密度と中位の 相関関係 (シルト: $r=0.58$, 粘土: $r=-0.57$ )を示した. 乾燥密 度は $\theta_{s}$ と高い負の相関関係を $(r=-0.87)$ 示した. $\theta_{s}$ は飽和の 体積含水率であるため, 完全飽和された試料であれば, 乾燥密度と限りなく相関係数は-1に近づく. 本試験では, 毛管飽和を採用したため, 間隙が完全に飽和されなかっ たと考えた。 $\alpha, n$ および $K_{s}$ と粒度分布は低い相関関係もし くは無相関であった. 乾燥密度は $K_{s}$ と負の中位の相関関 係関係 $(r=-0.57)$ を示した. これは, 乾燥密度が大きくなる ほどその土畩は固くなり, 透水性は低下寸るためであると 考えられた. MVGパラメータ間では, $n$ と $\theta_{r}$ は高い相関関 係を示した。 
植付け後経過期間は乾燥密度と高い正の相関 $(r=0.60)$, $K_{s}$ と中位の負の相関関係 $(r=-0.58), n$ と中位の負の相関関 係 $(r=-0.56)$ および年浸透量と高い負の相関関係 $(-0.66)$ を 示した. 図 4に示すように, それぞれの圃場においてばら つきはあるが, 植付け後の時間経過による乾湿の繰り返し
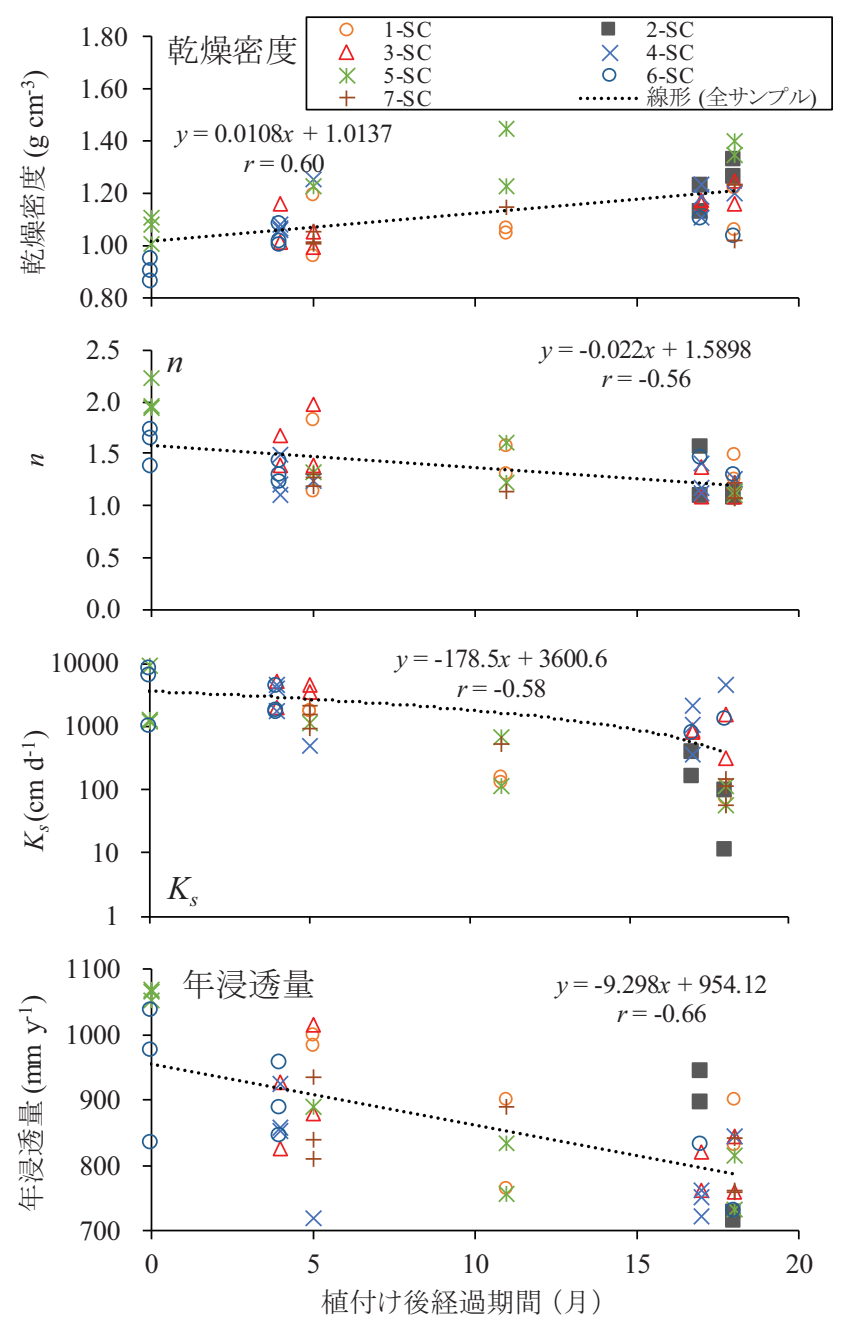

困 4: 植付け後経過期間と乾燥密度, $n, K_{s}$ および年 浸透量の関係
により，耕起時に破砕された作土層の土塊が崩壊したため， 大間隙が減少し透水性が低下したと考えられた. MVGパ ラメータnは, Carsel and Parrish(1988)らの報告によると, 粘 性の土壌は砂質の土壤に比べて小さい值を示す. 粒度分 布では，サンプリング時期の違いの影響が確認できないこ とから, 次の考察を行った. 耕起直後では, 土壤の大間隙 が発達していたため, 砂質土畩と同じように間隙での水分 保持力が低い特性を示した. そして, 植付け後からの時間 経過に伴う乾湿の繰り返しにより大間隙が減少することに より, 粘性土特有の微細な間隙による高い水分保持の特 性を示したと考えた. また, 年浸透量は, $n$ と高い正の相関 関係 $(r=0.70)$, 乾燥密度と中位の負の相関関係 $(r=-0.59)$, $K_{s}$ と中位の正の相関関係 $(r=0.55)$ を示した(図 5). Wang

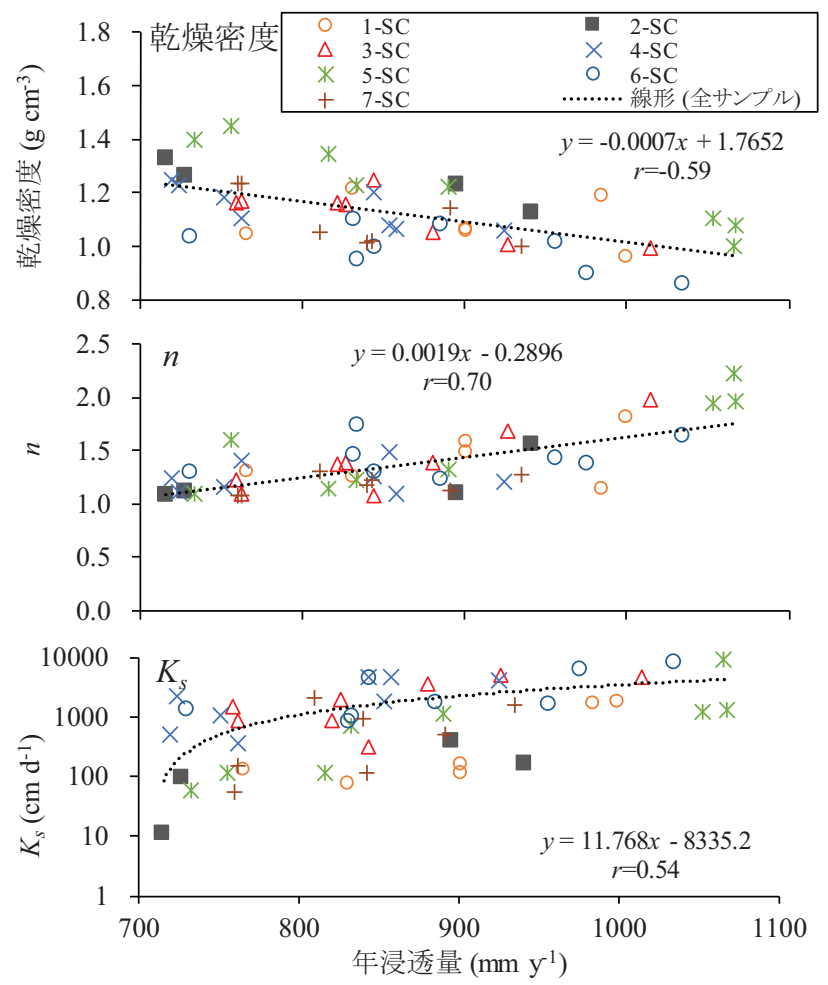

図 5: 年浸透量と乾燥密度, $n$ および $K_{s}$ の関係

表 6: 各変数の相関表 $(N=49, * * 1 \%$ 有意, $* 5 \%$ 有意 $)$

\begin{tabular}{|c|c|c|c|c|c|c|c|c|c|c|c|}
\hline & $\begin{array}{l}\text { 砂 } \\
(\%)\end{array}$ & $\begin{array}{l}\text { シルト } \\
(\%)\end{array}$ & $\begin{array}{l}\text { 粘土 } \\
(\%)\end{array}$ & $\begin{array}{l}\text { 乾燥 } \\
\text { 密度 } \\
\left(\mathrm{g} \mathrm{cm}^{-3}\right)\end{array}$ & $\begin{array}{l}\theta_{r} \\
\left(\mathrm{~cm}^{3}\right. \\
\left.\mathrm{cm}^{-3}\right)\end{array}$ & $\begin{array}{l}\theta_{s} \\
\left(\mathrm{~cm}^{3}\right. \\
\left.\mathrm{cm}^{-3}\right)\end{array}$ & $\begin{array}{l}\alpha \\
\left(\mathrm{cm}^{-1}\right)\end{array}$ & $\begin{array}{l}n \\
(-)\end{array}$ & $\begin{array}{l}K_{s} \\
\left(\mathrm{~cm} \mathrm{~d}^{-1}\right)\end{array}$ & $\begin{array}{l}\text { 経過期 } \\
\text { 間 } \\
\text { (月 })\end{array}$ & $\begin{array}{l}\text { 年浸 } \\
\text { 透量 } \\
(\mathrm{mm} \\
\left.\mathrm{y}^{-1}\right)\end{array}$ \\
\hline シルト & $0.56^{* *}$ & & & & & & & & & & \\
\hline 粘土 & $-0.81 * *$ & $-0.94 * *$ & & & & & & & & & \\
\hline 乾燥密度 & $0.39 * *$ & $0.58 * *$ & $-0.57 * *$ & & & & & & & & \\
\hline$\theta_{r}$ & $-0.32 *$ & $-0.48 * *$ & $0.47 * *$ & $-0.52 * *$ & & & & & & & \\
\hline$\theta_{s}$ & $-0.48 * *$ & $-0.68 * *$ & $0.68 * *$ & $-0.87 * *$ & $0.54 * *$ & & & & & & \\
\hline$\alpha$ & 0.04 & -0.12 & 0.06 & -0.08 & -0.19 & 0.19 & & & & & \\
\hline$n$ & $-0.30^{*}$ & -0.28 & $0.32 *$ & $-0.48^{* *}$ & $0.69^{* *}$ & $0.42^{* *}$ & $-0.38 * *$ & & & & \\
\hline$K_{s}$ & -0.16 & -0.19 & 0.20 & $-0.58 * *$ & 0.19 & $0.45^{* *}$ & 0.14 & $0.44 * *$ & & & \\
\hline 経過期間 & $0.42 * *$ & $0.44 * *$ & $-0.49 * *$ & $0.60 * *$ & $-0.49 * *$ & $-0.52 *$ & -0.05 & $-0.56^{* *}$ & $-0.58 * *$ & & \\
\hline 年浸透量 & $-0.36^{*}$ & $-0.35^{*}$ & $0.39 * *$ & $-0.59 * *$ & $0.47 * *$ & $0.53 * *$ & 0.03 & $0.70 * *$ & $0.54 * *$ & $-0.66^{* *}$ & \\
\hline
\end{tabular}


et al.(2009)は, 砂質・砂質ローム土㙴における HYDRUS-1Dの地下浸透量の推定においては, MVGパラ メータ $n$ に強く影響を受けることを報告している. MVGパラ メータ $n$ の值は大きくなると, 土袞吸引圧の減少に伴い, 土 壤水分および不飽和透水係数が急激に減少し水分移動 は少なくなる. そのため, 表層の根の吸水による蒸散量の 減少, 地表面からの蒸発量の減少により浸透量が増加し たと考えられた。

以上の結果より, サトウキビ畑における表層土壌のサン プリング時期の違いは, 時間経過に伴い乾燥密度の増加, 透水性の低下およびnの減少により, 浸透量の減少に影 響を与えることが示唆された。

\section{2 クラスター分析による土壤サンプルの類型化}

植付け後経過期間, 土壤物理性, MVGパラメータ, 年浸 透量の類型化を検討するため, x-means法によるクラスタ 一分析を行った. なお，变数間の物理的意味合いが近く 相関が高い粒度分布では, 砂分, シル下を除外し, 乾燥密 度と $\theta_{s}$ では, $\theta_{s}$ を除外した. x-means法によるクラスター数は 4に分類され, 各クラスターの標準化した変数の平均值を レーダーチャートとして, 図 6に示した.

クラスター1では, 4つのクラスターの中で, 最も付け後の 経過期間が短く, $n, K_{s}$ および年浸透量が大きかった. 表 7に示寸各戋場の代表的クラスターより, クラスター 1 は, 植 付け後経過5か月以内に出現していることより, クラスター1 に分類されたサンプルは, 耕起の影響により大間隙が発 達し, 透水性が高かったと考えられた. クラスター2では, 分類されたサンプルは少なく $(N=4), K_{s}$ および年浸透量は 大きかった. クラスター3およびクラスター4においては, 植 付け後の経過時間は長く, 年浸透量は小さかった. クラス ター3では, $K_{s}$ が小さく, クラスター4では, 乾燥密度が大き

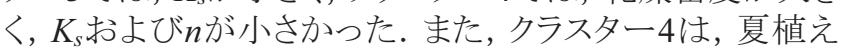
栽培の 2 年目に相当する植付け後経過期間 17,18 だけで 出現した。

各戋場における植付け後経過期間とクラスターの関係 では, 概ねどの戋場も植付け後の時間経過に伴い, 地下 浸透量が多いクラスターの順 $(1 \sim 4 の$ 順 $)$ で出現した. ま た，植付け後経過期間5か月以内では，クラスター 1 が 出現し, 11か月以降ではクラスター3およびクラスター 4が出現した. 実戋場においては, 植付け後5〜6か月以 内では, 栽培管理として除草のための中耕や培土が行 われる。そのため, 表層の土壌は膨軟な状態であると 考えられる。それ以降では，台風によるサトウキビの 倒伏などにより収穫後まで, 表層の土壤構造に影響を 与える耕転機が戋場に入ることは稀である。したがっ て, 植付け後期間11か月以降では, 時間経過により土
表 7: 各戋場の植付け後経過期間における代表的クラ スター

\begin{tabular}{ccccccc}
\hline 調查戋場 & \multicolumn{6}{c}{ 植付け後経過期間 } \\
(月) \\
1-SC & 0 & 4 & 5 & 11 & 17 & 18 \\
2-SC & & & 1,2 & 1,3 & & 3 \\
3-SC & & 1 & 1 & & 3,4 & 3,4 \\
4-SC & & 1,2 & 3 & & 3,4 & 2 \\
5-SC & 1 & & 3 & 3 & & 3 \\
6-SC & 1 & 1 & & & 3 & 3 \\
7-SC & & & 1 & 3 & & 3,4 \\
\hline
\end{tabular}

袞が締め固まったため, ほとんどの戋場でクラスター3 およびクラスター4が出現したと考えた.

\section{3 確率水文量の推定}

計算期間 30 年間での表面流出および土壤水分の変化量 は $1 \%$ 以下であった. これは, 土壤の透水性が高く, 降雨の 長期的な増減傾向は確認できないためである.したがって, 降雨, 蒸発散, 浸透を対象とした. 図 7に, 全ての計算結 果の年積算量の箱ひげ図および5年間の移動平均値を示 寸。

図 7より蒸発散量の年変動は小さいことが確認できた. これは, 降雨量が十分あり, 計算上では作物の吸水の制 限要因となっていなかったと考えられた。一方, 浸透量は 年変動が大きく, 長期的な変動傾向では浸透率 (浸透量) 降雨量) と同じ傾向を示した. ここで, 土壤水分の変化と表 面流出を除外した水収支式は，浸透率を用いることにより 次式で示せる.

$$
\text { 浸透率 }=1-\frac{\text { 蒸発散 }}{\text { 降雨 }}
$$

蒸発散量の年変動が少ないため, 浸透率は降雨に依存 する. そのため, 浸透量, 浸透率の長期変動傾向は同じ 傾向を示した. 地下浸透率の全計算結果の 30 年間の平均 值は0.41であり, 宮古島の一般的に用いられている浸透 率0.4(黒田・古川, 2002) と概衩同じ值となった。

図 8に各クラスターの浸透量と浸透率の中央值, 降雨 および非超過確を確率紙にプロットした結果を示す.グラ フの目盛は横軸には対数目盛, 縦軸は正規確率目盛で ある. 浸透量および浸透率は, 全ての非超過確率で右側 から左側にクラスター1〜4の順でプロットされた. 線形回帰 を行った, 各クラスターの10年確率(非超過確率 $10 \%$ )の 浸透量および浸透率の統計值を表 8に示す.

10 年確率の浸透率 (量) の中央值で比較すると, 最大の クラスター 1 と最小のクラスター4では, 0.07 (浸透量: $\left.114.1 \mathrm{~mm} \mathrm{y}^{-1}\right)$ の差があることが確認できた. 表 8から降雨
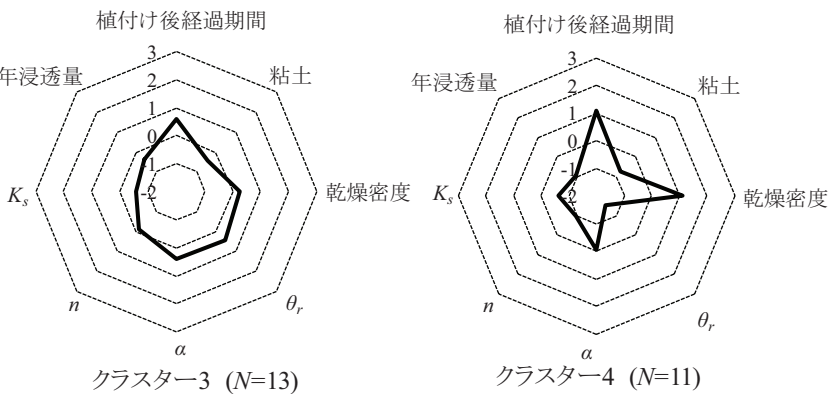
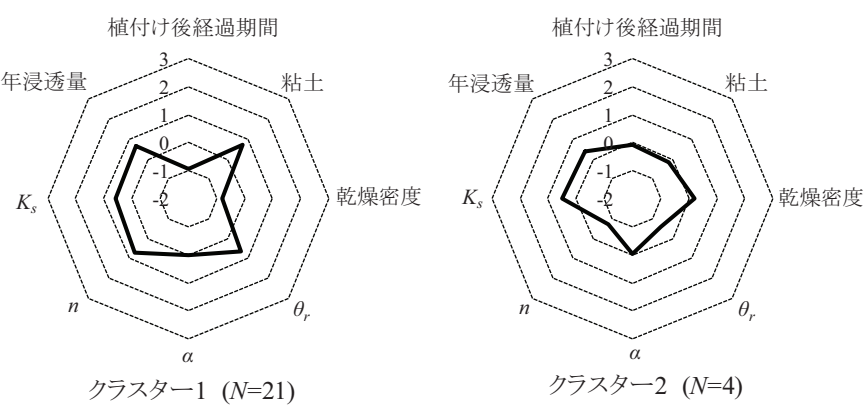

図 6: 各クラスターにおける標準化した変数の平均值 

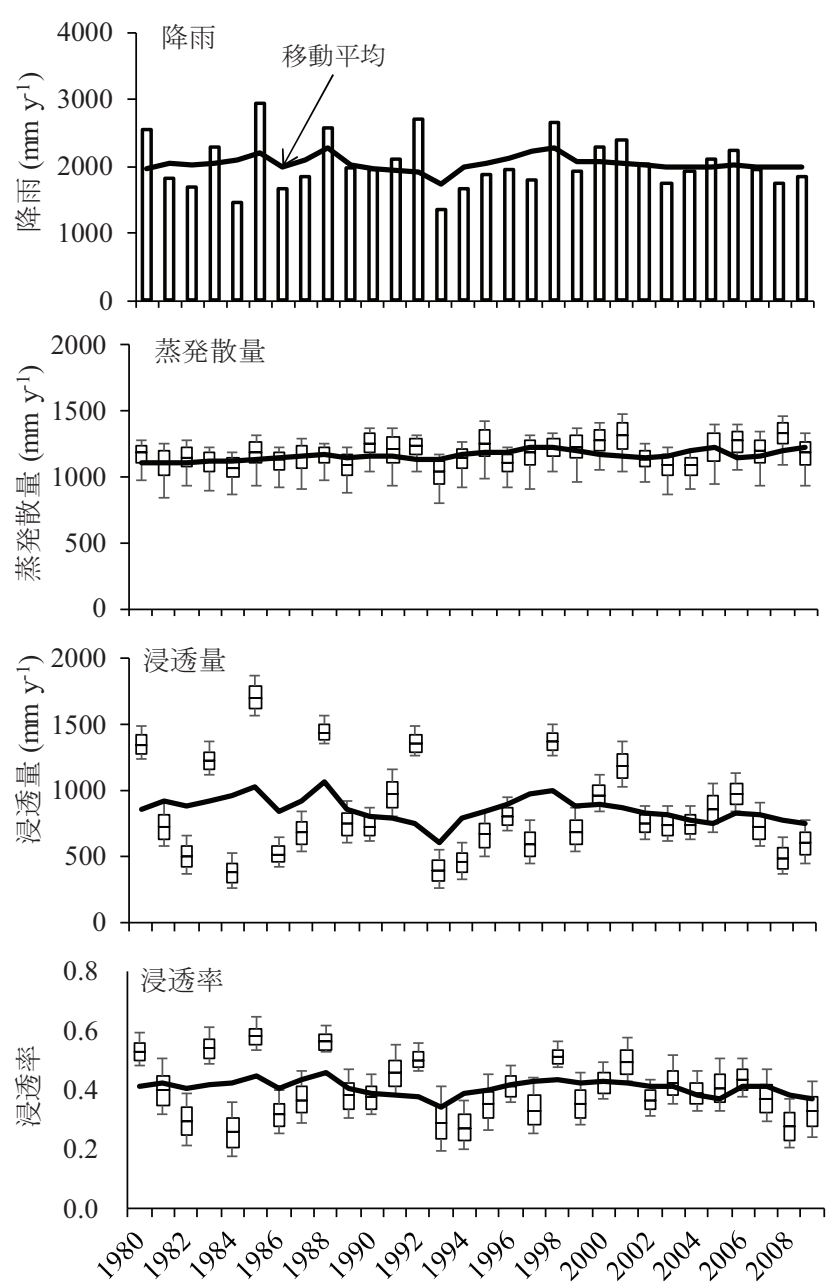

図 7: 降雨量, 蒸発散量, 地下浸透量, 浸透率の経年変 化

(=浸透量/浸透率)を求めると, 全てのクラスターの統計值 において1540mm程度である. 図 8の降雨の回帰線より10 年確率年降雨を求めると $1548 \mathrm{~mm}$ であり, 各クラスターの浸 透率と浸透量より算定された值とほぼ同じであった。これ は, 式(7)で示したように, 浸透率は浸透量に依存するため であり，全てのクラスターにおいて，10年確率の浸透が発 生する年降雨は同じ10年確率年降雨であった。

このように, 不飽和浸透解析に用いる土壌のサンプリン グの時期の違いによって, サトウキビ畑における浸透量の 確率水文量の評価に影響を及ぼすことが確認できた。

\section{4 おわりに}

サトウキビ畑における土壌物理性の時間変化および土㙋 物理性の時間変化が不飽和浸透解析に及ぼす影響を検 討した。 土壌物理性の時間変化は, 最も耕転および乾湿 の繰り返しの影響を受けることが考えられる表層土畩を対 象として, 粒度分布, 乾燥密度およびMVGパラメータの相 関を確認した。

植付け後からの時間経過は, 粒度分布には影響がなく, 乾燥密度の増加, $n$ および $K_{s}$ の減少する結果が得られた。 これは耕転および乾湿の繰り返しの影響により, 表層の土 塊が崩壊し土壌が締め固まることにより, 透水性の低下し たためと思われる.

計算結果である年浸透量は植付け後からの時間経過
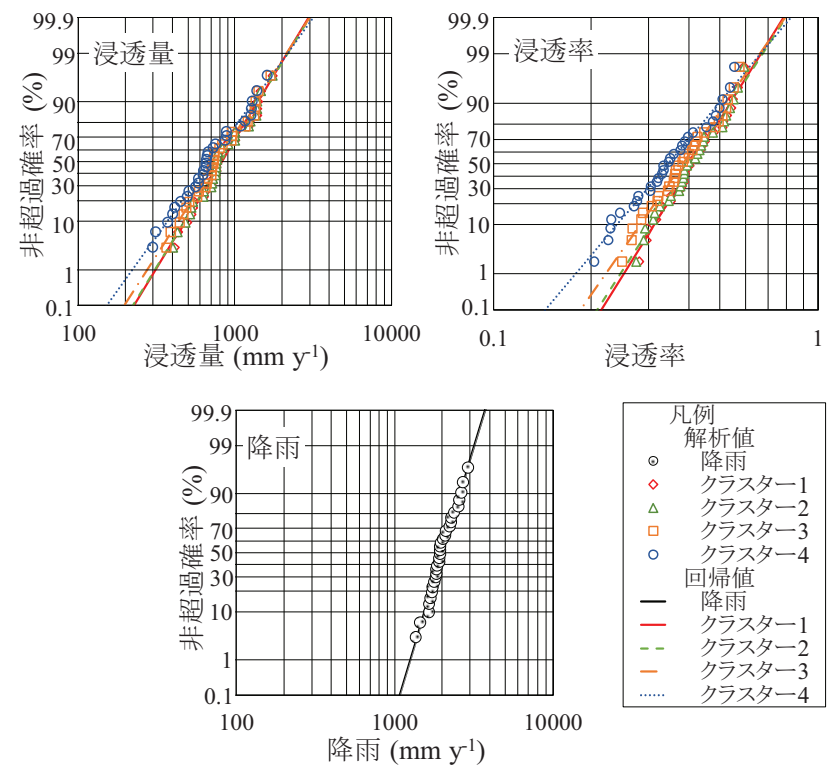

図 8: 非超過確率と各クラスターの浸透量および浸透率の 中央值および年降雨の関係

表 8: 10年確率の浸透率および浸透量の統計值 ([]内は 浸透量 $\left.\left(\mathrm{mm} \mathrm{y}^{-1}\right)\right)$

\begin{tabular}{cccccc}
$\begin{array}{c}\text { クラス } \\
\text { ター }\end{array}$ & $\begin{array}{c}\text { サンプ } \\
\text { ル数 }\end{array}$ & 中央值 & 最大值 & 最小值 & $\begin{array}{c}\text { 標準 } \\
\text { 偏差 }\end{array}$ \\
\hline 1 & 21 & 0.31 & 0.41 & 0.22 & 0.05 \\
& & {$[482.7]$} & {$[658.0]$} & {$[346.4]$} & {$[82.0]$} \\
2 & 4 & 0.30 & 0.42 & 0.21 & 0.09 \\
& & {$[475.0]$} & {$[590.1]$} & {$[43.0]$} & {$[65.4]$} \\
3 & \multirow{2}{*}{13} & 0.28 & 0.35 & 0.22 & 0.04 \\
& \multirow{2}{*}{11} & {$[436.1]$} & {$[703.2]$} & {$[518.8]$} & {$[51.0]$} \\
4 & & 0.24 & 0.42 & 0.21 & 0.07 \\
& & {$[368.6]$} & {$[665.6]$} & {$[338.2]$} & {$[111.8]$} \\
\hline
\end{tabular}

に伴い減少する傾向を示した. これは, 計算に用いるパラ メータ $\theta_{s}, n$ および $K_{s}$ 年浸透量と相関関係にあり, これら のパラメータの時間変化が不飽和浸透解析に影響をして いるといえる.

クラスター分析により分類された4つのクラスターでは, 10 年確率の浸透率の中央值は, 最大のクラスター 1 と最小 のクラスター4で0.07の差があることが確認できた. クラスタ -1 に分類される土䁃は植付け後から 1 年以内, クラスター 4 に分類される土䁃は植付け後 2 年目の土壤であることか ら, 不飽和浸透解析に用いる土壌のサンプリング時期 により浸透量の推定に影響を及ぼすことが示唆された.

\section{引用文献}

[1] 相場瑞夫・黒川睦夫・長田 聡・細谷裕士・吉川 満 (1988): 宮古島における地下ダムの水文挙動, 土と基礎, 31-3(302), pp.17-23.

[2] Campbell, G.S. (1988): Soil physics with basics, transport models for models for soil-plant systems, Dunod, New York, p.144.

[3] Carsel, R.F., and Parrish, R.S. (1988): Developing joint probability distribution of soil water retention characteristics. Water Resour. Res., 24, pp.755-769. 
[4] 㴊上吾郎・仲江川敏之・沖大幹・虫明功臣 (1993): 土袞 サンプリングデータの空閒代表性, 37, 水工学論文集, pp.849-852.

[5] 長谷川周一・前田隆 (1977): 土壌構造の破壊が水分保 持特性および不飽和透水係数に及ぼす影響について一 不飽和土壤水の運動に関する研究 ( II ) - , 農土論集, 72, pp.22-29.

[6] Hoffman, G.J., and Van Genuchten, M.T. (1983): Soil properties and efficient water use: Water namagement for salinity control, Limitations and Efficient Water Use in Crop Production, Am. Soc. Of Argon., Madison, WI, pp. 73-85.

[7] 今泉真之・前川統一郎・長田実也・富田友幸 (1988): 宮 古島地下ダム計画の水理計算シミュレーションについて, 地下水学会誌, 30(1), pp.11-23.

[8] 石岡恒憲 (2000): クラスター数を自動決定するk-means アルゴリズムの拡張について, 応用統計学, 29(3), pp.141-149,

http ://www.rd.dnc.ac.jp/ tunenori/xmeans.html(2016年12 月 12 日確認).

[9] 黒田登美男・古川博恭 (2002): サンゴの島の地下水保 全一「水危機の世紀を迎えて」, 宮古島地下水水質保全 対策協議会・宮古島広域圈事務組合・宮古島上水道企 業団, pp.64-65.

[10] 小杉賢一朗 (2007): 古典を読む:Y. Mualem著「不飽和 多孔質体の透水係数を推定する新たなモデルについて」 ならびにM. Th. van Genuchten著「不飽和土壤の透水係 数を推定する閉形式解について」, 土壤の物理性, 106, pp.105-112.

[11] Larsbo, M., and Jarvis, N. (2003): MACRO 5.0: A Model of Water Flow and Solute Transport in Macroporous Soil, Department of Soil Sciences, Swedish University of Agricultural Sciences: Uppsala, Sweden.

[12] Luckner, L., van Genuchten, M.Th., and Nielsen, D.R. (1989): A consistent set of parametric models for the two-phase flow of immiscible fluids in the subsurface. $\mathrm{Wa}$ ter Resour. Res., 25, pp.2187-2193.

[13] 宮古島市 (2011): 第3次宮古島市地下水利用計画, 宮 古島市, p.6.

[14] 宮古島市上下水道企業団 (1999): 平成11年度白川田・ 東添道・福里流域保全計画策定業務報告書, p.64.

[15] 宮里清松 (1986): サトウキビとその栽培, 日本分蜜糖工 業会, pp.106-107.

[16] Mualem, Y. (1976): A new model predicting the hydraulic conductivity of unsaturated porous media. Water Resour. Res., 12, pp.513-522.
[17] Nimmo, J.R. (1991) : Comment on the treatment of residual water content in "A consistent set of parametric models for the two-phase flow of immiscible fluids in the subsurface" by L. Luckner et al. Water Resour. Res., 27, pp.661-662.

[18] 農林水産省構造改善局 (1997): 土地改良事業設計基 準計画「農業用水 (畑)」基準書・技術書, 農業土木学会, pp.180-181.

[19] Okamoto, K., Sakai, K., Nakamura, S., Cho, H., Nakandakari, T., and Ootani, S. (2015): Optimal choice of soil hydraucil parameters for simulating the unsaturated flow: a case study on the island of Miyakojima, Japan, Water, 7(10), pp.5676-5688.

[20] 沖縄県宮古農林水産振興センター (2011): 宮古の農林 水産業, pp.26-27.

[21] 沖縄県農林水産部 (2014): さとうきび栽培指針, 沖縄県 農林水産部, p.58.

[22] 翁長謙良・宜保清一 (1984): 日本の特殊土壌 (その11) 一 沖縄の特殊土壌 (マージ, ジャーガル) 一, 農土誌, 52, pp.517-524.

[23] 坂本康・穴水大介・平松公明・熱田洋一・西田継 (2003): 表層不飽和土壃層での溶質移動パラメータの空間分布 特性と観測スケールの影響，水工学論文集，47， pp.301-306.

[24] Šimůnek, J., and Suarez, D.L. (1993): Modeling of carbon dioxide transport and production in soil: 1 . Modeling development. Water Resour. Res., 29(2), pp.487-497.

[25] 田中宏平・四尔所四男美 (1981): 宮古島の地下水予測 に関するシステム理論的研究, 九大農学芸誌, 35(3・4), pp.97-103.

[26] Van Genuchten, M.T. (1980): A closed-form equation for predicting the hydraulic conductivity of unsaturated soils. Soil Sci. Soc. Am. J., 44, pp.892-898.

[27] Van Genuchten, M.T. (1987): A numerical model for water and solute movement in and below the root zone, Resarch report no121, US Salinty Laboratory, Reverside California.

[28] Wang, T., Zlotnik, V.A., Šimůnek, J., and Schaap, M.G. (2009): Using pedotransfer functions in vadose zone models for estimatin, groundwater recharge in semiarid region. Water Resour. Res., 45, doi:10.1029/2008WR006903.

[29] 山城三郎 (1983): 沖縄におけるサトウキビのカンガイ用 水量決定に関係ある2,3の要素に関する研究, 琉球大学 農学部学術報告, 30, pp.367-488.

[30] 吉永安俊・酒井一人 (2004): 石灰岩地帯の圃場整備に おける有効土層深に関する研究 一サトウキビを事例とし て一，農土誌, 72, pp.1-9.

この論文の公開の質疑または討議は2018年6月30日 まで受付けます. 